\title{
Systematics and mode of life of a new Silurian Clisospira (Mollusca) from North Greenland
}

\begin{abstract}
John S. Peel
Abstract

Clisospira ellitsgaardi sp. nov. is described from the Cape Schuchert Formation (Early Silurian) of Washington Land, western North Greenland. The cancellate ornamentation of the sinistrally coiled molluscan shell is produced by the interference of successive crenulate growth lamellae. The wide frill of $C$. ellitsgaardi may have hindered sinking into soft bottom sediment or increased shell stability by increasing the surface area of the underside of the shell. The strongly tangential aperture probably indicates that $C$. ellitsgaardi effectively clamped its shell against the substratum when disturbed.
\end{abstract}

Gastropods are molluscs which are characterised by having undergone torsion at some stage in their development. This is a process whereby the mantle cavity with its contained gills and anus is rotated anticlockwise from the original posterior position to lie anteriorly above the head. Torsion produces internal asymmetry clearly visible in virtually all gastropods, although it is modified to varying degrees in most lineages by a series of processes including loss of one set of the originally paired organs and subsequent de-torsion. In some advanced opisthobranchs, the modifications are so complete that traces of torsion are barely discernible.

Most gastropods have a well developed calcareous shell which is typically anisostrophic, i.e. coiled into the familiar helical spire (fig. 1). Some have isostrophic, symmetrically coiled or cap-shaped shells, while others have reduced the shell to an internal plate or even lost it altogether. The helical, or conispiral, shell form is so typical, however, that it is often incorrectly assumed that this form of coiling is itself related to the process of torsion.

The great majority of living gastropods have a dextral shell, i.e. one in which coiling is clockwise when the shell is observed from the apex, looking down the axis of coiling. When the shell is placed in standard orientation for description, with the apex upward and the aperture facing the observer, the aperture thus lies to the right of the axis of coiling (fig. 1). Much less frequently, the shell is sinistral, i.e. coiling is anticlockwise when the shell is viewed from the apex, and the aperture lies to the left in standard orientation (fig. 1). Dextral coiling also dominates the fossil record of gastropods, although examples of genera, species or individuals with sinistral coiling are known from all the geological systems.

Most gastropods are orthostrophically coiled which, in a simplistic manner, is best described by considering that the shell in standard orientation grows down the axis of coiling (fig. 1) and that the protrusion of earlier whorls forms a true spire. Very rarely, at the present day, hyperstrophic coiling also exists, i.e. coiling in which shell growth can simplistically be considered to take place by translation up the axis of coiling; thus, the protrusion of earlier whorls is on the under surface, in standard orientation, and is termed 'a basal spire'. Hyperstrophic shells may also be dextral or sinistral which, if it were not for the great rarity of living hyperstrophic shells, could cause considerable systematic confusion, since an or- 


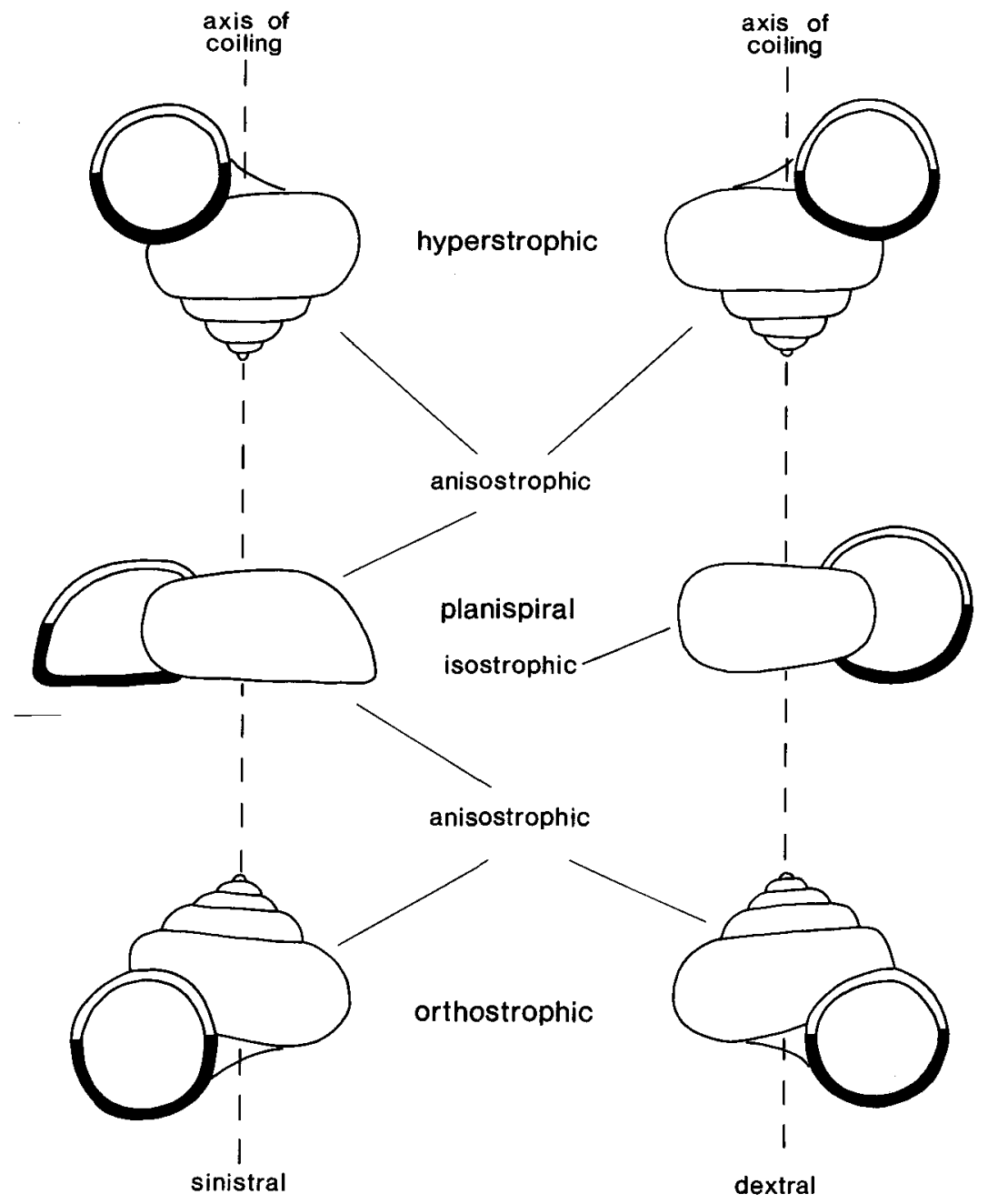

Fig. 1. Nomenclature of shell coiling in gastropods and related molluscs. Corresponding areas of the whorl profile are arbitrarily indicated (black), but it is evident that the sinistral hyperstrophic shell (top left) is identical in form to the dextral orthostrophic shell (lower right) when both are oriented with the apex pointing in the same direction.

thostrophic sinistral shell could be virtually indistinguishable from an hyperstrophic dextral shell, or an orthostrophic dextral from an hyperstrophic sinistral (fig. 1). With the animal in place, the problem is less severe, since the gastropod in a dextral shell (orthostrophic or hyperstrophic) is organised dextrally; a sinistrally organised gastropod would be a mirror image of its dextral counterpart.

The operculum, the calcareous or organic plate which partially or completely closes the aperture in many gastropod shells after withdrawal of the animal, provides conclusive evidence of orthostrophy or hyperstrophy. When viewed externally, the operculum coils in the 

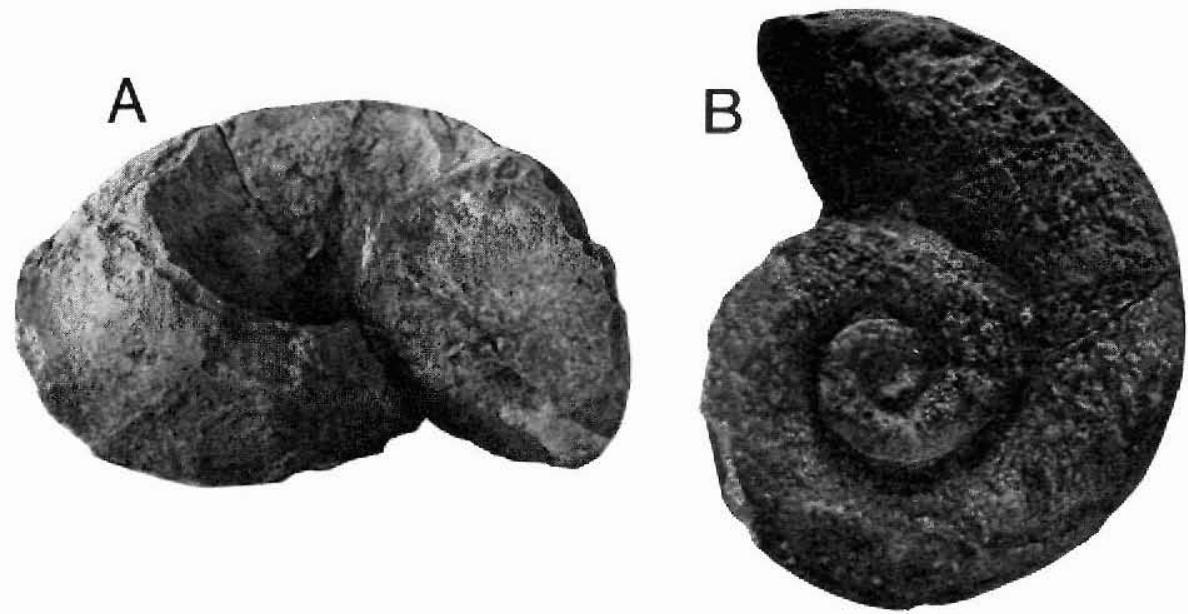

Fig. 2. Maclurites sp., internal mould, MGUH 16.780 from GGU sample 271684, Børglum River Formation, Late Ordovician, Peary Land, central North Greenland, $\times 1$. A, oblique view of upper surface in life position, showing the dextral hyperstrophic coiling. B, axial view of the flattened basal surface. Without evidence from the operculum, this surface would be expected to represent the upper surface, and coiling would be interpreted as sinistral orthostrophic (cf. fig. 1). Sinistral coiling in the operculum, however, demonstrates that the shell is dextrally coiled and that orientation as in fig. $2 \mathrm{~A}$, with an apical umbilicus and flattened basal spire, is correct.

opposite direction to the true direction of coiling of the shell. Thus, a means exists for detecting hyperstrophy in the fossil record where information on the organisation of the gastropod, as distinct from its shell, is lacking. Unfortunately, gastropod opercula are uncommon in the Palaeozoic, and associations of shell and operculum are rare (Yochelson, 1979). In Maclurites, however, the operculum is well known (Rohr, 1979) and it can be demonstrated that the shell in this genus, which is common in the Ordovician of Greenland (Troedsson, 1928), is dextral hyperstrophic rather than sinistral orthostrophic. Maclurites should thus be oriented for description with the spire pointing down (i.e. as a basal spire) and the aperture to the right (fig. 2A). In fact, the basal spire is almost flat and in life the gastropod was sedentary, lying with this surface on the sea-floor.

Maclurites and allied genera form a well defined group of Cambrian - Ordovician hyperstrophic genera. Clisospira and other onychochilins form a second group of more uncertain position, but they are generally placed in proximity to the macluritins. As in macluritins, the shell appears sinistral, but it is usually restored as dextral hyperstrophic, although no operculum confirming this reconstruction has been described. Onychochilins are known from the Lower Cambrian to Devonian and possess a well developed basal spire. They are widespread and diverse (Horný, 1964; Wängberg-Eriksson, 1979) but are infrequent in described faunas.

It is unusual and remains unexplained why hyperstrophic shell forms are quite common in the Lower Palaeozoic but exceedingly rare at the present day. Macluritins were sedentary and probably ciliary suspension feeders. Their shell form can be viewed as the result of this mode of life, with hyperstrophic growth being produced by the inhibiting effect of the under- 
lying sediment surface. Ciliary feeding is well known at the present day and cemented forms, such as Vermetus and Vermicularia, tend also to grow up, away from the sediment, although without being considered hyperstrophic. The onychochilins are more difficult to explain since the well-developed basal spire prevents restoration in the manner of Maclurites, with basal spire in contact with the sediment surface. If hyperstrophic coiling is accepted, the shell in life must have projected anteriorly above the head of the snail (Linsley, 1977) in contrast to orthostrophic gastropods where the apex of the shell points posteriorly or posterolaterally. Thus, the basal spire of standard orientation points upwards during life in similar fashion to the true spire of normal gastropods!

An alternative is that onychochilins were not hyperstrophic at all (although most shell features suggest that they were) and that the group forms a parallel but sinistral development to the dextral gastropods. The sinistral lineage was long-lived (Cambrian - Devonian), but not as successful as the dextral lineage (Cambrian - present day). Such an hypothesis would require that torsion took place on at least two occasions, once to the right and once to the left.

A third possibility has recently been proposed by Linsley \& Kier (1984), who suggest that the onychochilins, macluritins, pelagiellaceans and possibly the euomphalins were not gastropods at all. Linsley \& Kier refer these groups to a Class Paragastropoda, while admitting that they form a rather heterogeneous association and not a single evolutionary lineage. Paragastropods are considered to be anisostrophically coiled, un-torted molluscs. Their anisostrophic shell form is shared with the Gastropoda, although the latter are by definition torted. That the Cambrian pelagiellaceans are not gastropods is widely accepted, but the concept of a Class Paragastropoda is as yet too untried to evaluate. At first glance, the need to include the euomphalins is not apparent, and the pelagiellaceans may also belong elsewhere. Linsley \& Kier's discussion highlights, however, the complexity of molluscan history in the Lower Palaeozoic. Their complicated analysis of functional morphology serves to demonstrate that the currently described Clisospira ellitsgaardi sp. nov. offers a glimpse of a dead-end in molluscan evolution, rather than just a simple snail which decided to coil to the left instead of to the right.

\title{
Systematic palaeontology
}

\author{
Superfamily Onychochilacea Koken, 1925 \\ Family Clisospiridae Miller, 1889 \\ Subfamily Clisospirinae Miller, 1889 \\ Genus Clisospira Billings, 1865
}

Type species. Clisospira curiosa Billings, 1865.

Discussion. Linsley \& Kier (1984) followed Horný (1964) in assigning Clisospira and Ferrogyra Horný, 1964 to this subfamily. The latter is most readily distinguished from Clisospira by its lack of cancellate ornament; in Ferrogyra, ornament consists of prosocline ridges. Ferrogyra is also lower spired than Clisospira, with a wide umbilicus.

Linsley \& Kier (1984) placed the Onychochilacea within a new order Hyperstrophina of their Class Paragastropoda. More traditionally, onychochilaceans are placed within the suborder Macluritina of the prosobranch gastropod Order Archaeogastropoda; Peel (in press) informally recognised onychochilins as a separate sub-order equivalent in status to Maclurites and its allies. 
Clisospira ellitsgaardi sp. nov.

Fig. 3A-G

Derivation of name. For Knud Ellitsgaard-Rasmussen, first director of the Geological Survey of Greenland (GGU).

Material. The holotype, MGUH 16.778, and one paratype, MGUH 16.779, from GGU collection 216842, Cape Schuchert Formation, Early Silurian, Kap Schuchert, Washington Land, western North Greenland. A full description of the enclosing strata is given by Hurst (1980). Clisospira ellitsgaardi is a rare element in a fauna with abundant brachiopods and trilobites, originally described by Poulsen (1934).

Diagnosis. A Clisospira with a low basal spire, relatively few whorls and a wide peripheral frill; cancellate ornament on the whorl surface gives way to strongly prosocline ribs on the outer frill.

Description. A species of Clisospira with at least three whorls; the apex and nuclear whorls are unknown. In later whorls, the profile of the outer whorl surface is convex, slightly shouldered, but passes with concave curvature on to the wide peripheral frill; umbilical surface not known. In axial view, the frill appears as wide as the whorl itself on the final whorl, although the transition from whorl to frill is not clearly defined. The frill is flat peripherally, in an asymptotic relationship to the underlying sediment surface in the preserved position, with the apex up and the axis of coiling vertical; this position is also the presumed life orientation. The aperture is poorly known but is probably elliptical in cross-section, with the long axis of the ellipse sloping outward from the suture with the previous whorl toward the junction with the frill. The aperture is tangential to the previously coiled whorl and strongly prosocline. Shell ornamentation is cancellate; sharp transverse ridges are separated by concave interspaces that are crossed by spiral ridges which are less pronounced than the transverse elements. Spiral ridges are discontinuous from one radial interspace to the next and are themselves separated by concave interspaces. Spiral ridges are largely absent from the frill, where ornament consists of fine transverse ribs which are more prosocline and four or five times more abundant than the pronounced transverse ridges of the whorl surface. The shell is apparently quite thin; its structure is not known.

Comparison with other species. Clisospira ellitsgaardi is lower spired, with fewer, more rapidly expanding whorls than the type species, $C$. curiosa Billings, 1865, originally described from the Lower Ordovician of Quebec, Canada. In addition, the frill of the Greenland Silurian species is wider and its outer areas show replacement of the cancellate ornamentation by abundant, fine, strongly prosocline ribs. C. reticulata Longstaff, 1924, from the Upper Ordovician Drummock Group of southern Scotland, is lower spired than the type species, but differs from C. ellitsgaardi in apparently possessing an ornamentation of reticulate cords. C. balclatchiensis Longstaff, 1924, from the Lower Ordovician of the same area, has only strongly prosocline ornamentation. As noted by Longstaff (1924, p. 439), this species closely resembles Onychochilus helmhackeri Perner, 1900, the Clisospira helmhackeri (Perner, 1900) of Perner (1911). C. helmhackeri is type species of Mimospira Koken \& Perner, 1925, and $C$. balclatchiensis is probably better located within the latter, non-frilled genus. 

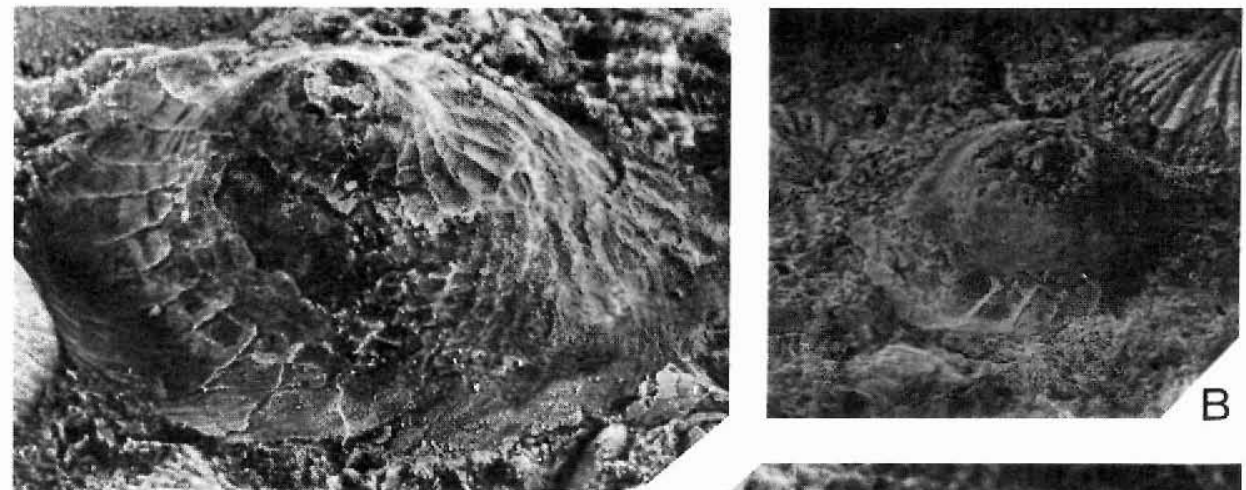

A

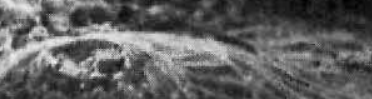


Clisospira rugosa Koken, 1925, as figured by Wängberg-Eriksson (1979) from the Ordovician of Östergötland, Sweden, does not closely resemble the type species, as illustrated by Knight (1941). It may not be a Clisospira, and as such is readily distinguished from $C$. ellitsgaardi by its higher spire, lack of cancellate ornamentation and lack of the wide, flat frill.

Clisospira schucherti Perner, 1903, from the Silurian of Bohemia, the type species of Conoclisa Horný, 1964, is higher spired than C. ellitsgaardi. In addition, the whorl profile is concave between sutures and the ornamentation apparently lacks spiral elements. Clisospira antiqua Perner, 1907, and C. indentata Perner, 1907, also Bohemian species, appear to have the same general form as $C$. ellitsgaardi, but with a narrower frill and only transverse ornamentation.

Ferrogyra antiqua (Perner, 1903), the type and apparently only known species of the genus, appears to have a similar rate of whorl expansion to that of $C$. ellitsgaardi, but lacks cancellate ornamentation. Cancellate ornamentation is present in Laeogyra gracilis Perner, 1925 of Wängberg-Eriksson (1979), Pervertina Horný, 1964 and Invertospira Horný, 1964; all three Ordovician forms show cancellate ornamentation, but lack the frill characteristic of C. ellitsgaardi.

\section{Cancellate ornamentation in Clisospira ellitsgaardi}

The ornamentation of $C$. ellitsgaardi is unusual, not only on account of its cancellate pattern, a feature it shares with some other species of Clisospira and unrelated gastropods, such as some species of the bellerophontiform Bucania Hall, 1847, but also on account of the change in style of ornamentation from the whorl surface to the peripheral frill (fig. 3). As in some Bucania, it appears that the cancellation is not the result of intersecting spiral and transverse elements, but rather a pattern produced by the interference of successive crenulated lamellose growth elements (fig. 4). The perfection of the cancellate pattern makes it difficult to trace this mode of formation on the whorl surface in C. ellitsgaardi. However, close examination of the transitional area between whorl surface and frill appears to confirm that the strong transverse ridges of the whorl surface do not represent successive stages of the apertural margin. Rather, they are composite structures produced by the interference of successive crenulated lamellae (fig. 4). A more correct impression of the obliquity of the outer lip is gained from the fine transverse ribs seen near the frill periphery. Close examination reveals that many of these transverse ribs are in direct continuation with immediately adjacent spiral elements. Thus, the outer lip in C. ellitsgaardi is probably more strongly prosocline, i.e. swept more obliquely back from the previous suture, than the pronounced transverse ridges of the whorl surface would suggest (fig. 4C).

Fig. 3. Clisospira ellitsgaardi sp. nov., Cape Schuchert Formation, Early Silurian, Kap Schuchert, Washington Land, western North Greenland. A, C-F, MGUH 16.778 from GGU sample 216842, holotype, × 7.5. A, C, D, F, are oblique lateral views of the basal spire showing well developed cancellate ornamentation on the whorl succeeded by oblique radial ornamentation on the peripheral frill; $\mathrm{E}$, axial view. B, G, MGUH 16.779 from GGU sample 216842, paratype, $\times 5$. Poorly preserved specimen in oblique lateral and axial views. 

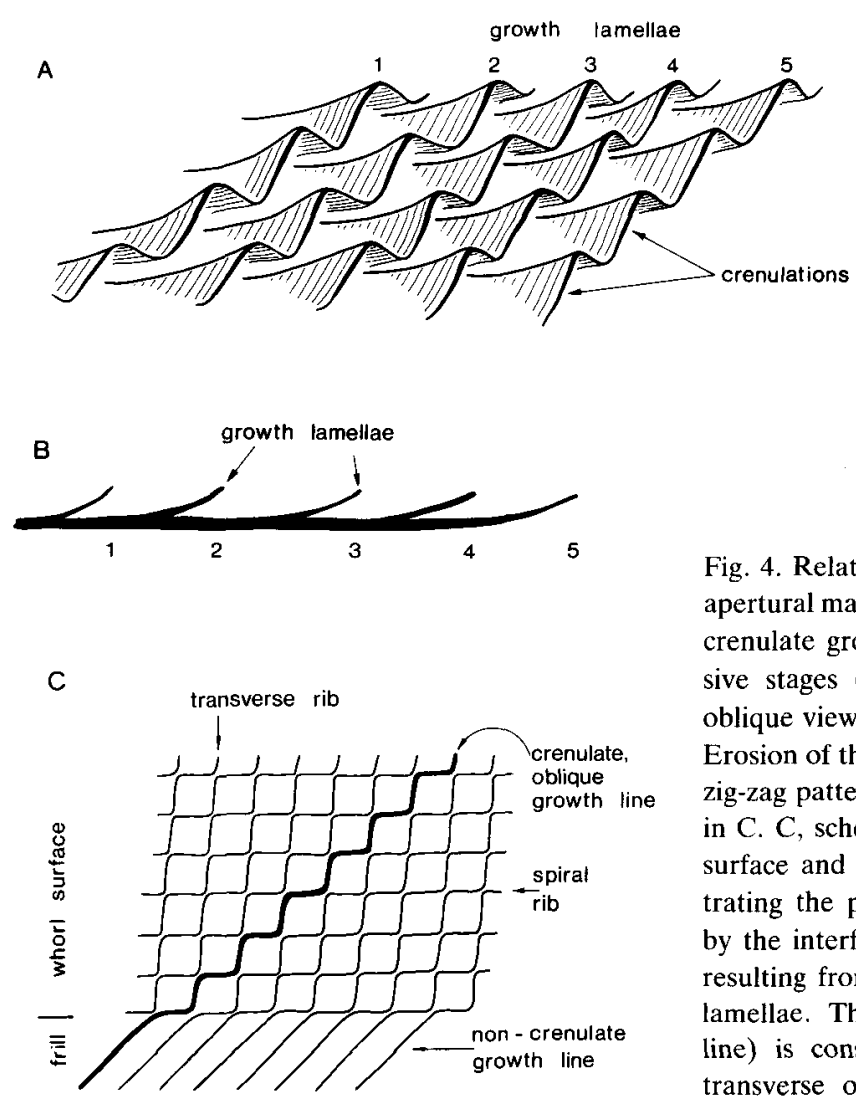

Fig. 4. Relationship between ornament and the apertural margin in Clisospira ellitsgaardi. A, B, crenulate growth lamellae representing successive stages (1-5) of the apertural margin in oblique view (A) and in cross-section (B).

Erosion of the projecting lamellae produces the zig-zag pattern for individual growth lines seen in C. C, schematic representation of the whorl surface and frill of Clisospira ellitsgaardi illustrating the production of cancellate ornament by the interference of the zig-zag growth lines resulting from the erosion of crenulate growth lamellae. The true apertural margin (growth line) is considerably more oblique than the transverse ornament.

\section{Mode of life of Clisospira ellitsgaardi}

The function of the frill and peripheral spines in a number of present-day and Lower Palaeozoic gastropods has been discussed by Linsley et al. (1978), particularly with reference to the familiar Silurian gastropod Euomphalopterus Roemer, 1876 (fig. 5). The resemblance between this latter genus and $C$. ellitsgaardi is striking, notwithstanding that Euomphalopterus is a true gastropod with torsion and clockwise coiling when viewed from above the apex, while Clisospira is considered by Linsley \& Kier (1984) to be an untorted paragastropod with anticlockwise coiling in apical view. Specimens of Euomphalopterus are also commonly many times larger than described examples of Clisospira.

Linsley et al. (1978) noted that a downward directed circlet of spines or a frill might serve to support the living animal above the substrate. The morphological adaptation is seen in living Xenophoridae, which are rather immobile deposit feeders living on firm but penetrable substrata. In some Recent astraeinids, the circlet of spines is directed not downwards, but outwards from the whorl periphery. In such cases, the spines clearly do not serve a propping function, but may instead serve to prevent sinking of the animal into a soft substratum. In deep water astraeinids with long spines, the hypothesis of prevention of sinking by increase 


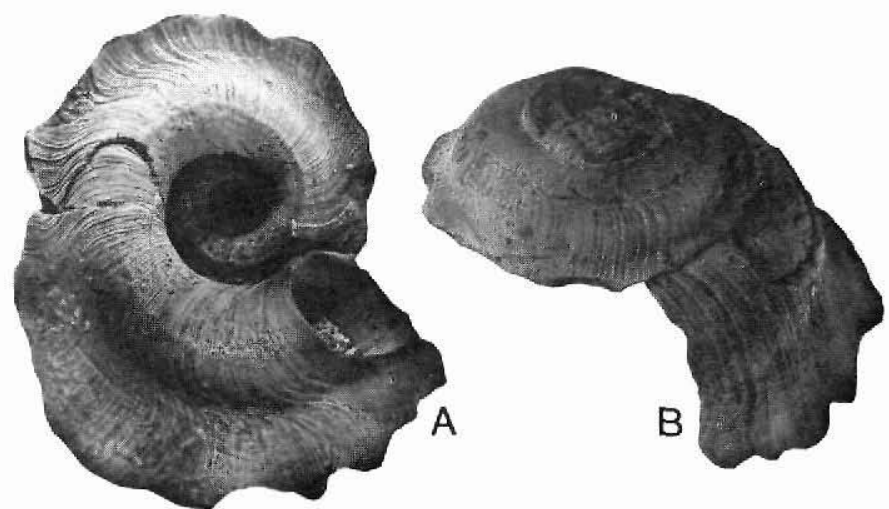

Fig. 5. Euomphalopterus alatus (Wahlenberg, 1821). Mo 27021, Högklint Beds, Silurian, Visby, Gotland, Sweden. Basal (A) and oblique lateral (B) views showing the well developed peripheral frill and sub-radial aperture, $\times 1$.

of surface area is viable. Most astraeinids, however, apparently live on hard substrata in the surf zone, where this 'snow-shoe' functional interpretation of the spine circlet is clearly inappropriate. Peripheral spines in such a high energy environment may help to prevent tipping by increasing shell width relative to height.

The frill in Euomphalopterus is commonly directed downwards, suggesting that it served to prop the animal above the sediment-water interface. In some specimens, however, the frill is directed outwards and in these cases the 'snow-shoe effect' can be invoked (Peel, 1984).

The frill in C. ellitsgaardi probably did not provide an effective propping function, since it rapidly becomes parallel to the substrate. It accounts for more than half the area of the undersurface and, as such, does provide a most effective snow-shoe.

A considerable difference between Euomphalopterus and C. ellitsgaardi is the nature of the aperture. In the former, the plane of aperture is sub-radial, although inclined to open slightly downwards. Such an aperture cannot be effectively clamped against the substratum which lends support to the interpreted propping function of the frill - a gastropod aperture clevated above the substratum can hardly clamp against the substratum when the animal is disturbed. The aperture in C. ellitsgaardi is much more perfectly tangential, a result produced by the pronounced prosocline obliquity of the outer lip. C. ellitsgaardi was probably an effective clamper when disturbed.

Thus, shell form in C. ellitsgaardi combines a wide brim reflecting an efficient 'snow-shoe' effect with a tangential aperture permitting clamping against the sediment surface.

Linsley et al. (1978) noted that a frill is not well-developed in juvenile Euomphalopterus and speculated that juveniles might have been more active than adults which consequently acquired an enlarged frill in response to their assumed more sedentary existence. Several authors (e.g. Knight, 1941) have commented that small specimens of Clisospira also lack a frill, which implies a parallel life history to that suggested in Euomphalopterus. This trait is confirmed in C. ellitsgaardi where early whorls seemingly possess a much reduced frill. 
Acknowledgements. MGUH and Mo denote the type collections of the Geological Museum, Copenhagen, and the State Museum of Natural History, Stockholm, respectively. Esben Glendal and Bente Thomas assisted in preparation of the manuscript.

\section{References}

Horný, R. J. 1964: New Lower Palaeozoic gastropod genera of Bohemia (Mollusca). Čas. národ. mus. 133, 21-216.

Hurst, J. M. 1980: Silurian stratigraphy and facies distribution in Washington Land and western Hall Land, North Greenland. Bull. Grønlands geol. Unders. 138, 95 pp.

Knight, J. B. 1941: Paleozoic gastropod genotypes. Spec. Pap. geol. Soc. Am. 32, 510 pp.

Linsley, R. M. 1977: Some 'laws' of gastropod shell form. Paleobiology 3, 196-206.

Linsley, R. M. \& Kier, W. M. 1984: The Paragastropoda: a proposal for a new class of Paleozoic Mollusca. Malacologia 25, 241-254.

Linsley, R. M., Yochelson, E. L. \& Rohr, D. M. 1978: A reinterpretation of the mode of life of some Palaeozoic frilled gastropods. Lethaia 11, 105-112.

Longstaff, J. 1924: Descriptions of Gasteropoda, chiefly in Mrs. Robert Gray's Collection, from the Ordovician and Lower Silurian of Girvan. Quart. Jl. geol. Soc. London 80, 408-446.

Peel, J. S. 1984: Autecology of Silurian gastropods and monoplacophorans. Spec. Pap. Palaeontology 32, 165-182.

Peel, J. S. in press: Class Gastropoda. In Boardman, R. S., Cheetham, A. H. \& Rowell, A. J. (edit.) Invertebrate Paleontology. San Francisco: Blackwell Scientific Press.

Perner, J. 1911: Gastéropodes Tồme 3. In Barrande, J., Systême silurien du centre de la Bohême 4, $390 \mathrm{pp}$.

Poulsen, C. 1934: The Silurian faunas of North Greenland. I. The fauna of the Cape Schuchert Formation. Meddr Grønland 72(2),1, 46 pp.

Rohr, D. M. 1979: Geographic distribution of the Ordovician gastropod Maclurites. In Gray, J. \& Boucot, A. J. (edit.) Historical biogeography, plate tectonics, and the changing environment, 45-52. Oregon State Univ. Press.

Troedsson, G. 1928: On the Middle and Upper Ordovician faunas of northern Greenland. Meddr Grønland 72(1),1, $197 \mathrm{pp}$.

Wängberg-Eriksson, K. 1979: Macluritacean gastropods from the Ordovician and Silurian of Sweden. Sver. geol. Unders. Afh. Series C, 758, 1-33.

Yochelson, E. L. 1979: Gastropod opercula as objects for paleobiogeographic study. In Gray, J. \& Boucot, A. J. (edit.) Historical biogeography, plate tectonics, and the changing environment, 37-43. Oregon State Univ. Press. 